\title{
Regionalization of Water Supply and Sewerage Companies as a Solution for the Efficiency of Water Supply and Sewerage Sector: Case of Albania
}

\author{
Evis Gjebrea, PhD Candidate \\ European University of Tirana, Albania \\ Email: evis.gjebrea@uet.edu.al \\ Oltjana Zoto, PhD \\ European University of Tirana, Albania \\ Email: oltjanazoto@yahoo.com
}

\section{Doi:10.5901/mjss.2013.v4n6p37}

\begin{abstract}
The aim of this paper is to analyze the efficiency of water supply and sewerage sector in Albania. The study focuses on the current situation of water supply and sewerage companies for the entire year 2011, as well an analysis of factors creating premises for achieving efficiency benefits. For the purposes of this study an analysis of three performance indicators that have a serious impact on the financial sustainability of a typical water and sewerage company is carried out using the data from the Performance Monitoring and Benchmarking Program for all water companies in Albania. The data are calculated based on weighted average basis for groupings of water companies/utilities using the "population served" by the company as the basis of "scale". The main result of the analysis is that the potential for economies of scale can exist in the case of Albania since $74 \%$ of water supply and sewerage companies serve a number of populations of less than 50,000 inhabitants. The result of the analysis shows that an increase in served population will normally be related to an increased population density, which also direclty contributes to achieving economies of scale and getting above a served population of 100,000 people are where economies of scale can start to make a real difference. In order to achieve this efficiency, the aggregation of companies and creation of regions may be the solution for this efficiency to be realized.
\end{abstract}

Keywords: Regionalization, Water and Sewerage Company, Economies of Scale, Population Served

\section{Introduction}

On a global level water is becoming a rare resource and there are several factors that cause this phenomenon such as global warming, population growth causing pressure for more water and demographic changes, meaning population move from rural to urban areas. In the past, water was treated a free or social commodity. But in the wake of increased competition for this commodity which is becoming rare a debate has started on new approach to water management.

These debates became part of the discussion in the International Conference for Water and Environment (Dublin, Ireland, 1992) in which were defined the main principles of water sector for sustainable development. These principles stipulate that water is a limited resource, essential to life, development and environment, has an economic value and its management should be based on a participatory model that includes planners, users and policy makers at all levels. Easter and Feder (1996) reached the conclusion that it is necessary a review of methods used to manage and allocate water according to the needs of customers and sectors.

Biswas (2001) states that "the day when the water is treated as a free commodity and provided automatically by the government is coming to an end." Tortajada (2001) analyzes that in the next decades water problems will increase and it will be required to analyze it in combination with other sectors such as agriculture, health, industry and environment. In this framework, the water will be seen in the context of the development of society, having as main objectives the reduction of poverty, sustainable development and environmental protection. These new developments in the design and further development of water management raised the necessity of drafting new water policies and strategies. In this respect, on 23 October 2000 the European Union developed the Water Framework Directive (2000/60/EC) for water resources management, which establishes the general framework of the use and management of 
water resource efficiency and provides a single water management through river basins as the natural geographical and hydrological unit, in contrast to the administrative and political boundaries.

Although the public sector can provide services at low prices, it damages the poor due to inability to make investments and as a result water quality is poor (Gray, 2001). There is a vast literature proving that private markets for water bring efficiency gains and are able to properly allocate water in other sectors (Easter and Hearne, 1995; Chang and Griffin, 1992; Colby, 1990; Crane, 1994). In this context, one of the ways that governments take into consideration is the involvement of the private sector through public-private partnerships to facilitate government budgets and provide better quality services. A matter of debate on private sector participation in the water supply and sewerage sector in developing countries is the efficiency of this sector. An important element of efficiency, which is also one of the benefits of Public Private Partnerships (PPPs) is reaching economies of scale.

This study aims to analyse regionalization as one way to improve the efficiency of the water and sewerage sector in general and particularly in Albania having as main criteria that of reaching "economies of scale".

\section{Literature Review}

Decentralization of water service delivery to local government especially in developing countries has raised challenges both in terms of management and financing. This is because local governments often do not have adequate capacity to serve a large number of citizens, as well as difficulties in securing the necessary funding to maintain water supply and sewerage networks and carry out necessary investments.

These difficulties and water management responsibilities at local level are reflected in the inefficiency of water supply and sewerage companies reflected by performance indicators. According to OECD (2006) the difficulties encountered in the water and sewerage sector are the following:

- High fixed costs associated with irreversible long-term investments;

- Water other than a basic need, has also other externalities such as the environment, health;

- Water is managed at the local level, therefore risks faced are those at the local level;

- Organization of the sector is complex where many actors and responsibilities are fragmented across agencies that are under the dependence of the government.

A matter of debate on private sector participation in water supply and sewerage sector in developing countries is the efficiency of this sector considering as the efficiency criteria "economies of scale". In microeconomic theory economies of scale are the cost advantages that a company realizes when it expands and increases production.

Economies of scale are debated especially for water and sewerage companies in developing countries that have the following characteristics:

- Companies are inefficient and therefore the services provided are not qualitative. These companies are not able to carry out investments to repair older systems, or to maintain existing systems;

- Due to the impossibility of carrying out necessary investments, the services in poor or remote areas cannot be provided. This leads to inequality in service delivery and environmental pollution;

- Water companies being different in size are fragmented and the involvement of the private sector is difficult due to lack of profits that the private sector requires;

- Poor performance of companies exerts pressure on the Government, which is obliged to offer subsidies. The debate around this particularly from international institutions is that Governments offer more subsidies for operating costs and very little is done to direct them to people in need.

One of the ways of achieving economies of scale is the aggregation of some units, which will serve a wider number of customers. This is why many countries in order to ensure sector efficieny have followed aggregation policies through the creation of the so called regional water companies. According to Kingdom (2005) there are few publications regarding aggregation/regionalization. The World Bank is the institution that has conducted several studies and promotes this scheme in developing countries. The main reason for regionalization is to achieve economies of scale by providing services to a greater number of customers, as well as the possibility to access private sector funding, based on the grounds of economies of scale.

\subsection{Definitions and drivers of regionalization}

There are several definitions related to regionalization. Often this term is referred to as regionalization, consolidation or 
restructuring. Research Foundation in the Water Sector defines regionalization as "a form of cooperation between water systems to improve service and efficiencies including reducing costs" (AWWA Research Foundation, 2008). Regionalization can consist on 2 categories:

- Physical union of the systems and inteconnection where two or more units share a source water treatment or distribution systems interlinked with each other and;

- Regional consolidation consisting of non-physical union and specifically in the agreement for the management of satellites etc. So, the units remain physically separated, but through agreements they share together several aspects of management.

According to another author regionalization or aggregation is defined as the grouping of several municipalities into a single administrative structure for the provision of a particular service. These assembled structures can change in 3 dimensions (Kingdom, 2005):

- Scale: joint structures can aggregate 2 municipalities that are similar to each other, or several municipalities in a single region or over a wider territory;

- Purpose: joint structures can provide a single service (for example, group water supply) or all services offered starting from water extraction to treatment of wastewater.

- Process: Municipalities can form joint structures on a voluntary basis that are based on common interests, or at a higher level of government led by the interest of the general public. This aggregation may be temporary or permanent

The purpose of this aggregation is to share technical, financial and operational capabilities. According to Whitlatch \& Revell (1990) regionalization is described as the union of administrative, economic, social structures for improving national, regional and local objectives.

Although the definitions are different the reforms of aggregation of water supply and sewerage companies are undertaken mainly in places where water supply service management is inefficient, being this because the unit is too small to offer an efficient service, or because this service is decentralized at the local level improperly. A general conclusion is that regionalization is undertaken to solve a public problem.

The concept of regionalization is widely applied today both in developed and developing countries. There is a vast literature with case studies analyzing the main factors that have forced countries to go this way, as well as limitations or barriers which water sector faces. Regionalization is studied from theoretical and practical point of view. Some studies are scientific while others are subjective. As a general conclusion regionalization brings benefits from economies of scale and improvement of the environment through improved water management (Beecher, 1996).

As already mentioned in this paper the main factor for regionalization is to achieve economies of scale. This is particularly essential for small companies to which it becomes difficult to achieve economies of scale if they act alone. According to a western city projects (McFarlane, 2003) the reason to share access to waters are: financial, geographical interdependence, public health concerns, regulatory changes and public expectations. According to SMC Martin, Inc. (1983) regionalization favors economies of scale, as the total costs will be reduced by increasing the number of population served. Also in this contribute savings achieved from merging human financial and technological resources.

Many studies have been conducted to prove the hypothesis raised that water and sewerage services being natural monopoly product have the characteristics of economies of scale, which means lower unit costs by increasing production (Beecher, 1996). However, according to Beecher from the technical point of view there are different analysis in the literature showing the limitations of this benefit as economies of scale arising in the extraction and treatment of groundwater are limited from other operations such as transmission and distribution.

In United States of America the lack of economies of scale in the water sector at the local level is a matter that has been analysed in previous years (Clemens, 1959). Not every study supports the idea that economies of scale are the only criterion to justify regionalization. For example, Kim and Clark (1988) reached the conclusion that the natural monopoly cannot exist in the water sector suggesting that economies of scale are difficult to be achieved. Although this particular observation is not supported across literature when analyzing regionalization it is important to take into account the fact that efficiency may not always be achieved through economies of scale, or in other words economies of scale are limited and in this respect it comes a point when such economies begin to fall.

What these techniques offer is to compare the savings achieved by centralized water treatment compared to other costs such as the costs of infrastructure and water extraction. In economics this process is known as an optimization problem which means fulfillment of standards with a minimum cost. As mentioned by Clark and Stevie (1981) "by developing a defining relationship between total costs and the cost of acquisition of the plant and transmissiondistribution it is possible to find a point at which economies of scale fall". 
Since 1998 the most important studies that have evaluated economies of scale in the water sector are Kim and Clark (1998) in the United States, Garcia and Thomas (2001) in France, Kim and Lee (1998) in Korea and Mizutani and Urakami (2001) in Japan. All these econometric studies were successful to show that economies of scale are stronger for smaller water supply and sewerage companies and those economies of scale are more stable when the size of a company is determined by the volume of water produced. But these studies suggest that strong economies of scale exist when the number of connections or the population served is used as an indicator for the size of the company (Tynan and Kingdom, 2005).

The debate conducted nowadays regarding economies of scale is determining the limit after which the benefits are not realized. There are several international research studies aimed to see if there is any connection between the size and efficiency of the company. For example, the earliest econometric research (Garcia and Thomas, 2001) used data from high income countries and reached the conclusion that water service providers can realize cost benefits regardless of the size of the enterprises taking into account also small size enterprises.

A later conducted study (Tynan and Kingdom, 2005) used data from high low and medium developing countries and analyzed the relationship between company size and cost per unit of production. The result was that water companies can reduce operational costs per customer by increasing the scale of production. The study pointed out that economies of scale are better realized for small size companies that serve less than 125,000 consumers than for large companies to which economies of scale begin to decrease after a certain point. According to Tynan (2003) a sustainable scale factor is 0.8 , which means that a doubling of production causes costs to increase by $80 \%$. Mizutami and Urakami (2001) have found that in Japan water utilities has an optimal size and serves a total of $700000-800000$ poeple. If the number of residents is higher then this there is no benefit from the so-called economy of scale.The overall result is that in all the cases analyzed through various studies regionalization has as a key factor the improvement of efficiency through economies of scale.

Another driver of regionalization is the possibility of having access to finances in the form of loans, which would not be possible if operating companies/utilities would operate on a fragmented basis and increased opportunities for regional programs, from which facilities can be obtained in the form of grants. Increased access to funds creates opportunities for smaller companies to invest in their old networks and to allocate funds for maintenance of their exisiting networks. Regionalization is regarded as an opportunity to have access to integrated water resources management. Water Framework Directive (2000/60/EC) dated 23 October 2000 for the management of water resources establishes the premise for undertaking large projects and in this context the aggregation of smaller units with larger ones should be considered as a need to have access to EU funds.

The division of costs is another important driver for regionalization. Aggregation of two or more companies gives the potential to share the costs and have higher profit opportunities in a long-term period. This is an advantage for highcost companies, which benefit from low-cost companies, while for the latter the aggregation might be seen as a constraint as higher costs for them means higher tariff for their customers. Higher tariff could lead to social turbulence and Government intervention in the form of subsidies in the early stages of the aggregation will be required to mitigate the negative effects of increasing tariffs for lower cost service companies.

Finally, aggregation of companies consists of the aggregation of human resources. The new company that is created benefits from enhanced proffesional capacities who bring with them knowledge. Some authors however, have raised concerns about the disadvantages of regionalization. Rice (1979) argues that this process brings conflicts after losing control of the relevant local authorities of water service supply and financial consequences of transferring ownership to a regional organization. The author reaches the conclusion that a regional national program would not be appropriate and that the local government should be allowed the freedom to assess their unique needs, resources for the provision of this service.

\section{Research Methodology}

For the purpose of this study 57 water and sewerage companies in Albania are analyzed for the entire year 2011 considering the currently available data as documented in the Performance Monitoring and Benchmarking Program administered under the Albanian General Directorate of Water Supply and Sewerage. This data analysis has the main purpose to see weather there is rationale to consider regionalization as a way of achieving economies of scale in Albania and where can these economies start to be evident.

The Study considers three performance indicators that have a serious impact on the financial sustainability of a typical water utility namely: 
- Number of Staff per 1000 water plus sewerage connections;

- Total operating cost per cubic meter water sold and produced and bought;

- Direct operating cost coverage based on revenues and collections.

The data are calculated on a weighted average basis for groupings of water utilities using the "population served" by the company as the basis of "scale".

\section{Regionalization of Water and Sewerage Companies: Case of Albania}

In Albania operate 57 water and / or sewerage companies. Of these only two are public enterprises in the process of transformation into a joint stock company. Water companies were previously owned by central government, but in 2007 all companies were transferred to local government onwership in the framework of the decentralization process. Performance of water supply and sewerage companies is poor as shown by performance indicators in this sector. Companies generally face more or less same problems, regardless of their level which varies from one city to another.

Some of these problems are as follow (General Directorate of Water Supply and Sewerage, 2011):

- Relatively low level of water supply: $86 \%$ overall coverage of which $91 \%$ in urban areas and $62 \%$ in rural areas;

- Major loss of water due to amortization and large amounts of unaccounted water. The rate of loss (the produced water which enters the system, but does not generate any income) is $60 \%$ while same figure in Western Europe at 20\%. This is caused because the level of metering installation is low at less than $50 \%$ of links and at the same time there are illegal connections to the network;

- Wastewater service coverage is $62 \%$ in general;

- Drinking water rates are at low levels that cannot afford the cost. Financial productivity of labor is 1.19 , which means that operating costs are $19 \%$ higher than income. While this figure in Western Europe is 0.50 ;

- Continuity of water supply is 11 hours, while same figure in Western Europe is at 24 hours a day. Only two water companies (Korca and Librazhd) can provide 24 hours water pressure (Albanian Ministry of Public Works and Transport, 2011).

- Poor performance of water supply and sewerage companies exerts pressure on the Government, which has been obliged to offer subsidies which though at a decreasing trend still remain high. In 2005-2008 the total central government subsidies for water and sewerage companies covered $38 \%$ of operating costs, while in 2011 this figure was at about 20\% of operating costs (Albanian Ministry of Public Works and Transport, 2011). Today's debate and concern that international institutions raise is that subsidies are provided to cover operating costs instead of directing them to help people in need.

The attention of the International partners has been drawn to the water and sewerage sector in Albania because problems and failures caused seem to be the main threat to macroeconomic stability, sustainable growth and poverty reduction. Moreover, the sector of water supply and sewerage is linked to the performance of other sectors such as: health and environment.

Involvement of PPP in water supply and sewerage sector has been low and experiences vary according to the area of intervention. Specifically, the first example is the concession of Elbasan given to Berlinwasser International in 2002 for the former state-owned water utility that served the city of Elbasan. Although this concession was granted for 30 years it only lasted 5 years due to financial failures the concessionaire faced. Another case involving PPP is the management contract for "Four Municipalities" Durres, Fier, Lezhë, Saranda, which was implemented with the financial support of the World Bank. This contract ended at the end of August 2008 and can be considered as relatively successful based on performance indicators which improved significantly. Another example of PPP in the sector is the management contract of Kavaja given to Kredistanstalf Fur Wiederaufbau (KfW) having a 3-year term. The contract improved the functioning of the water company, but did not meet the targets set in the contract (Albanian Ministry of Public Works and Transport, 2011).

Albania is implementing the Stabilisation and Association Agreement with the final objective to become part of the European Union. This requires full compliance with EU directives in all sectors including water. Water Framework Directive (2000/60/EC) of 23 October 2000 for the management of water resources create premises to undertake large projects and in this context aggregation of smaller units into larger ones should be considered as a need for having access to IPA pre-accession funds. 


\subsection{Can Albania consider regionalization of the water and sewerage companies?}

In Albania, forty-two (42) of all water and sewerage companies/utilities serve populations of less than 50,000 people, of which 31 serve populations of less than 22,000, which indicate that there is a significant lack of "economies of scale". Additionally, due to significant internal migration of population toward urban centers over the last 15 years there is sound reason to believe that the potential for economies of scale can also exist. Size does make a difference and a rule of thumb suggests that getting above a served population of 100,000 people are where economies of scale can start to make a real difference. The 57 formal companies serve a population of approximately 2.5 million people. The frequency distribution of the sizes of the 57 utilities is presented in the graph below.

\section{Figure 1}

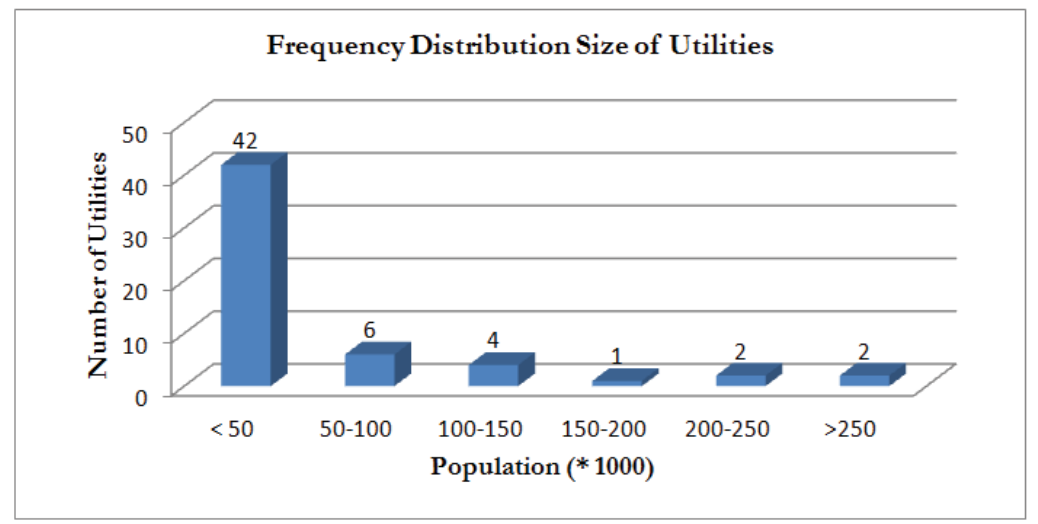

Source: Own graph, Database from Performance Monitoring and Benchmarking Program, 2011

The Central Government in the framework of the decentralization has transferred ownership of water company/utility assets to local government and this transfer has been completed in most of the companies in which local governments are the owners of the companies, while the companies themselves are administrators of these services. Although management roles are often separated media or different donors highlight conflicts between different levels of management, which in many times causes disagreements regarding the price of water and disapproval of proposals by the Municipal Council.

Within the European Union approach it is understood that the Central Government of Albania may be exploring a reduction in the number of regions as part of the EU requirement and this may result in a reduction of the numbers of Albanian regions from 12 to 6 or even to 4. Regionalization requires huge investments and funding and its provision from the government alone will be difficult. But on the other hand, regionalization may be an attractive way for foreign investors in the form of public-private partnership with the main argument of achieving economies of scale. Given the ownership of companies to local government units the challenge remains to find appropriate forms of PPPs in this sector that would bring together the interests of both parties.

In accordance with the National Strategy for Water Supply and Sewerage Sector 2011-2017 the Albanian government sees regionalization as a priority with common ownership and voting rights. Currently there is only one example in Albania of a pro-active aggregation in the Water Supply and Sewerage Sector. This was the aggregation of the Kucova Water Supply and Sewerage Company with the Berat Water Supply and Sewerage Company, facilitated by a grant provided by the German Development Bank (KfW) of Euro 6 million, which has been successful based on improved performance indicators.

A study conducted by Tynan and Kingdom (2005) looked at benchmarking data from 270 water supply and sanitation utilities across 33 countries. The authors state that the optimal size for utilities is more sensitive to customer characteristics than to the volume of water produced. These results and conclusions are supported in the case of Albania in the following analysis made for 57 water and sewerage companies. The study uses the data for the entire year of 2011 from Performance Monitoring and Benchmarking Program administered under the General Directorate of Water Supply and Sewerage. 
The following analysis considers 3 performance indicators that have a serious impact on the financial sustainability of a typical water utility:

- Number of Staff per 1000 water plus sewerage connections;

- Total operating cost per cubic meter sold and produced and bought;

- Direct operating cost coverage based on revenues and collections.

The data were calculated on a weighted average basis for groupings of water utilities using the "population served" by the utility as the basis of "scale".

Figure 2: Size Group Weighted Averages (Population Served)

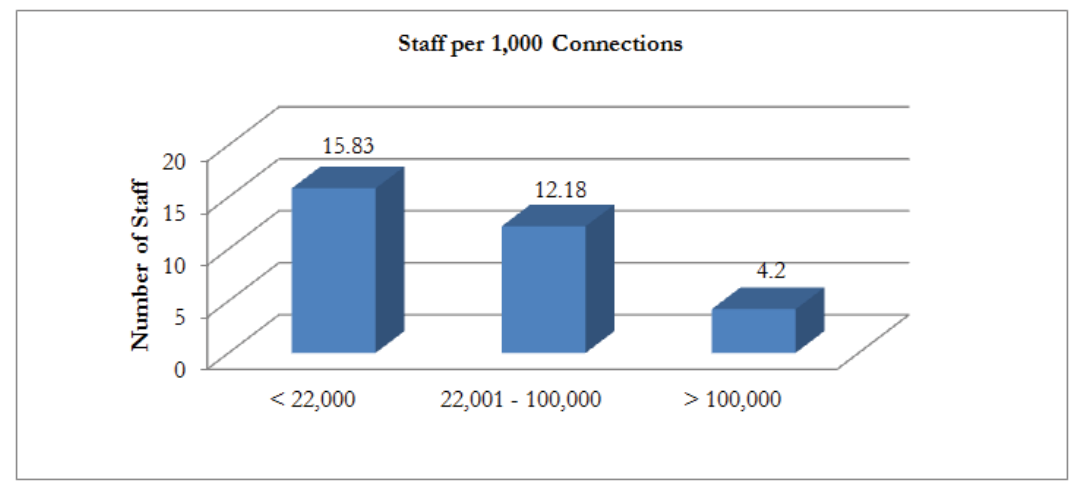

Source: Own graph, Database from Performance Monitoring and Benchmarking Program, 2011

The staffing efficiency indicator presented in Figure 2 shows an improvement in staffing efficiency with an increase in the size of the served population. Obviously, an increase in served population will normally be related to an increased population density, which also directly contributes to staffing efficiency. However, many of the larger water companies/utilities in Albania have some regional aspects to their service area, and therefore do include along with urban areas, rural areas.

Figure 3: Total Operating Cost per m3 Water Sold and Produced\& Bought Size Group Weighted Averages (Population Served)

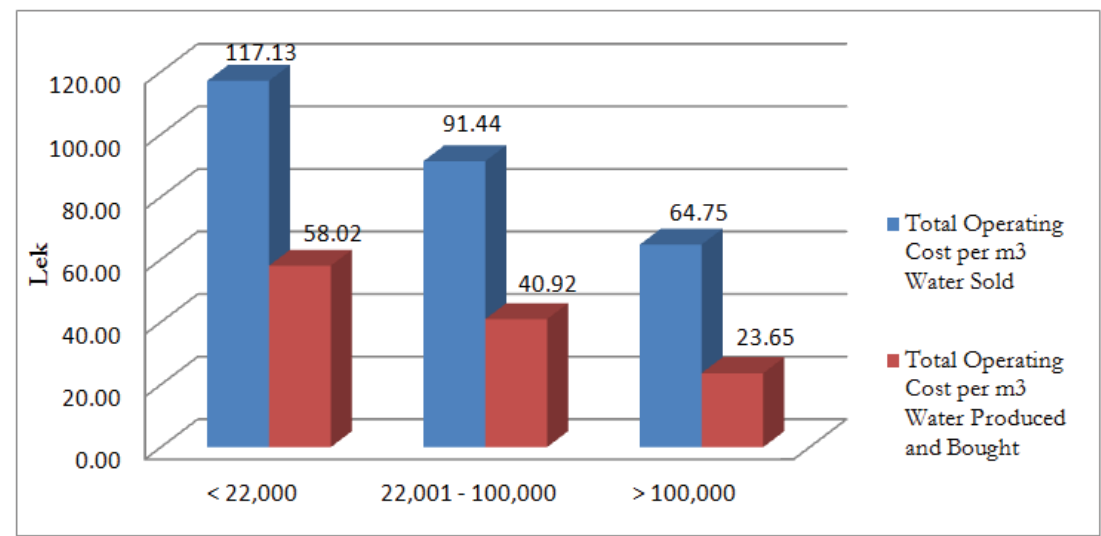

Source: Own graph, Database from Performance Monitoring and Benchmarking Program, 2011

Figure 3 gets to an economic specific. Since the product is water then the cost to produce that product in a free market is the determinate of competitiveness. As can be seen from the graph, although the "economy of scale" is not as dramatic as that regarding labor efficiency, the differences do exist and they are not insignificant. 
Figure 4: Direct Operating Cost Coverage Based on Revenues and Collections Size Group Weighted Averages (Population Served)

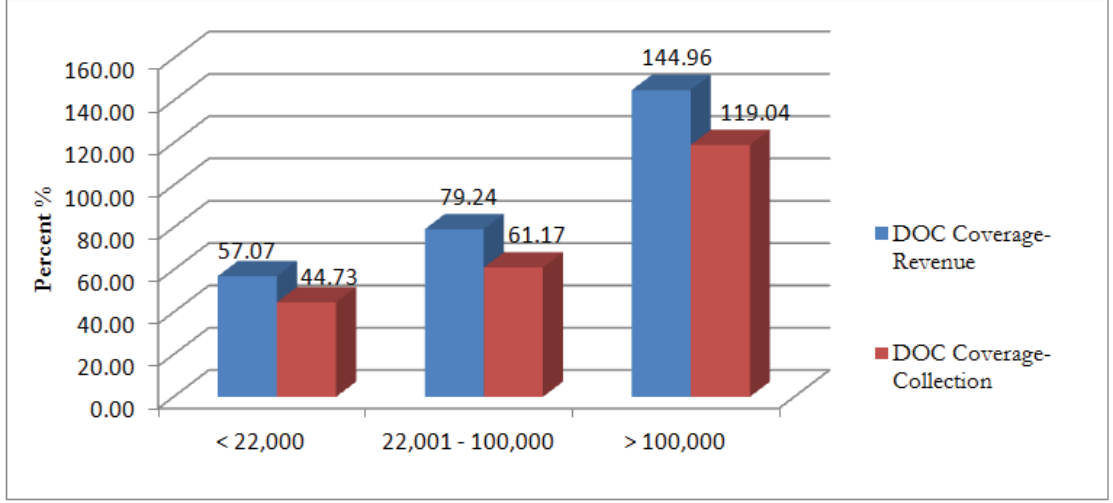

Source: Own Graph

Figure 4 tends to complete the logic related to discussions regarding the "economies of scale". So far the efficiency issue has been addressed related to labor and the cost issue has been addressed on the direct operating cost per m3 water sold and produced \& bought, then all that remains is to generate the cash flow to pay for it. The above graph considers "direct operating cost coverage" as a percentage of the revenues (total of amounts billed to all customers) and collections (total of amounts collected from all customers). Here again the larger utilities both bill a greater percentage of their total direct operating cost and cover in collections a greater percentage of their total operating costs, which confirms the efficiency logic from scale economy with an increase of population served.

\section{Concluding Remarks}

This paper analyses the concept and drivers of regionalization as a way of achieving efficiency in the water and sewerage sector in general and in the case of Albania in particular. The main factor of regionalization is to achieve economies of scale. Many previous econometric studies have shown that economies of scale are stronger for smaller water supply and sewerage companies and strong economies of scale exist when the number of connections or the population served is used as an indicator for the size of the company. In the case of Albania the study analysis the current situation of 57 water and sewerage companies and it was observed that the majority of companies serve a population of less than 50,000 people suggesting strong arguments for the existence of economies of scale. The three performance indicators analysed used data that were calculated on a weighted average basis for groupings of water utilities using the population served by the company/utility as the basis of scale. The result of the analysis shows that an increase in served population will normally be related to an increased population density, which also direclty contributes to achieving economies of scale.

\section{References}

Awwa Research Foundation, (2008). Regional Solution to Water Supply Provision, Second Edition, p. 2

Banka Boterore (World Bank) (2011). Decentralizimi dhe Realizimi i Shërbimeve në Shqipëri: Qeverisja në Sektorin e Ujit. [Available] Online http://siteresources.worldbank.org/INTALBANIA/Resources/Water Albanian.pdf

Beecher, J. (1996). The Regionalization of Water Utilities: Perspectives, Literature Review and Annotated Bibliography, p. 5

Biswas, A. (2001). "World Water Forum: in retrospect" Water Policy, Vol 3, pp 351-356

Chang, C., and Griffin, R. (1992). "Water Marketing as a Reallocative Institution in Texas" Water Resource Research, Vol.28, pp 879890

Clark, Robert M., and Richard G. Stevie. (1981). "A Regional Water Supply Cost Model," Growth and Change 12, no. 3, pp 9-16.

Clemens, E.I. (1959).Economics and Public Utilities, New York: Appleton-Century-Crots

Crane, R. (1994). "Water Markets, Market Reform and the Urban Poor: Results from Jakarta, Indonesia "World Development, Vol.22 (1), pp. $71-83$

Colby, B. (1990). "Transaction Cost and Efficiency in Western Water Allocation" American Journal of Agricultural Economics, Vol. 72 (5), pp.1184-1192 
Database of Performance Monitoring and Benchmarking Program, 2011 [Available] Online http://www.dpuk.gov.al/rub.php?idr=345\&lang=1

Directive 2000/60/EC amended with the directive 2009/31/EC me 23.04.2009 [Available] Online http://eur-lex.europa.eu/ LexUriServ/LexUriServ.do?uri=CONSLEG:2000L0060:20090625:EN:PDF

International Conference on Water and the Environment (Dublin, Ireland) in 1992

Easter, K.W., and Hearne, R.(1994). "Water markets and decentralized water resource management", Department of Agricultural and Applied Economics, College of Agriculture, University of Minessota

Easter, K.W., and Feder, G.(1996). "Water institutions and economic incentives to ameliorate market and government failures", Department of Applied Economics, College of Agriculture, Food and Environmental Science, University of Minessota

Garcia, S., and Thomas, A. (2001). "The Structure of Municipal Water Supply Costs: Application to a Panel of French Local Communities." Journal of Productivity Analysis 16 (1), pp. 5-29

Gray, P. (2001). "Private Participation in Infrastructure: a review of the evidence"

Kingdom, W. (2005). "Models of Aggregation for Water and Sanitation Provision", Water Supply and Sanitation Notes, Note No. 1, pp. 5, 21

Kim, H. Y., and Clark M.R. (1988). "Economies of Scale and Scope in Water Supply," Regional Science and Urban Economics 18, no. 4, p. 479

McFarlane, S. (2003). "Regional Water Works: Sharing Urban Water Services", Western Cities Project Report, No.28, p.5

Albanian Ministry of Public Works and Transport (2011). National Sector Strategy of Water Supply and Sewearge 2011-2017, p. 11, 24 [Available] Online http://www.erru.al/doc/Strategila Kombetare sektoriale e sherbimeve te furnizimit me uje dhe kanalizime 2011 - 2017.pdf

Rice, I. M. (1979). "Regionalization of Water Utilities: Disadvantages," Journal American Water Works Association, no. 5, p. 11.

SMC Martin, Inc (1983). "Regionalization Options for Small Water Systems", Washington, DC: U.S. Environmental Protection Agency, pp. $19,111-1$

Tortajada, C. (2001) "First Meeting of the Club of Tokyo"

Tynan, N. (2003). "Returns to Scale in Water Systems in Developing Countries: Some Econometric Evidence"

Tynan, N., and Kingdom, B. (2005). Optimal Size of Utilities?: Return to Scale in Water: Evidence from Benchmarking"

OECD (2006). "Private Sector Participation: Policy Framework for Investment"

Whitlatch, E., and Charles S. R (1990). "Regionalization in Water Resource Projects," Water International 15, no.2, pp. 70-80 
